\title{
INVASION OF ABANDONED AGRICULTURAL FIELDS BY ACACIA MEARNSII AFFECT SOIL PROPERTIES IN EASTERN CAPE, SOUTH AFRICA
}

\author{
RUWANZA, S. \\ Department of Environmental Science, Rhodes University, Grahamstown 6140, South Africa \\ e-mail: ruwanza@yahoo.com; tel: +27-46-603-7011; fax: +27-46-622-9319 \\ (Received 27 $7^{\text {th }}$ Jul 2016; accepted $6^{\text {th }}$ Oct 2016)
}

\begin{abstract}
Abandoned agricultural fields are susceptible to alien plant invasion because they experienced intensive anthropogenic activities. However, there is limited studies on soil physicochemical changes in alien plant invaded abandoned agricultural fields in comparison to uninvaded abandoned agricultural fields and natural sites. This comparative study explores soil physico-chemical changes in ten-year-old abandoned agricultural fields invaded by Acacia mearnsii in comparison to ten-year-old uninvaded abandoned agricultural fields and natural sites in Eastern Cape, South Africa. Soil physico-chemical properties were measured on topsoil collected from invaded and uninvaded abandoned agricultural fields as well as natural sites over three months. Results on soil nutrient changes between invaded and uninvaded abandoned agricultural fields compared to natural sites were varied, with significantly higher total $\mathrm{C}$ and cations of $\mathrm{Na}$ and $\mathrm{Mg}$ reported in A. mearnsii invaded abandoned agricultural fields, whereas soil $\mathrm{pH}$ and $\mathrm{P}$ were significantly higher in uninvaded abandoned agricultural fields. Soils underneath invaded abandoned agricultural fields were compact, had high litter mass, reduced infiltration and were repellent compared to soil in uninvaded abandoned agricultural fields and natural sites. It appears that the invasion of A. mearnsii in abandoned agricultural fields has triggered changes in soil physico-chemical properties.
\end{abstract}

Keywords: invasive alien plant; nutrient cycling; litter; soil water repellency; land use legacy

\section{Introduction}

Areas of abandoned agricultural fields are increasing globally (Chambers et al., 2014), due to geo-bio-physical, socio-economic and management factors (Rey Benayas et al., 2007). Agricultural fields are abandoned when they cease to generate an income or when opportunities for resource adjustments are exhausted (MacDonald et al., 2000). Abandoned agricultural fields characterize a change in land use and cover, which can affect ecosystem structure and function (Jiao et al., 2013). Lack of ecosystem recovery to the original condition following abandonment can result in loss of biodiversity, decreased structural heterogeneity, loss of soils and cultural values (Chambers et al., 2014). Hobbs and Cramer (2007) reported that abandoned agricultural fields can remain in a degraded state for decades leading to invasion by alien invasive plants. Factors that promote the invasion of abandoned agricultural fields by alien plants include elevated soil nutrients that favour productivity of alien plants, better competitive ability of alien invasive plants, increased seed productivity and dispersal of alien invasive plants and poor seed bank of native species (Hobbs and Cramer, 2007). Once alien invasive plants have invaded abandoned agricultural fields, they have been shown to modify biotic and abiotic soil properties (Hobbs and Cramer, 2007). The presence of alien species in abandoned agricultural fields has been shown to affect soil nutrients, nutrient cycles and soil microbial communities (Milton, 2004; Ruwanza et al., 2012). 
Acacia mearnsii (Black wattle) is one of the most invasive alien plants in South Africa (Dye and Jarmain, 2004). The plant is native to Australia, but has invaded most of the high rainfall regions of South Africa (Dye and Jarmain, 2004). The plant has been reported to cause biodiversity loss, reduced water supply, increased soil erosion and increased fire intensity (Le Maitre et al., 2011). Its success as an invasive alien plant is attributed to its ability to produce huge amounts of seed, persistent seed banks, capacity to fix nitrogen and ability to out-compete natives for resources like water and soil nutrients (Le Maitre et al., 2011). Several management interventions to control $A$. mearnsii in South Africa are underway, including measures to prevent introductions, mechanical and biological control (Le Maitre et al., 2011). However, these interventions have yielded mixed results when it comes to control and restoration efficacy (Esler et al., 2008). Therefore, improved and clearer understanding of $A$. mearnsii invasions, especially plant-soil interactions in abandoned agricultural fields which are susceptible to invasion, will help implementation of an effective $A$. mearnsii management strategy.

Most studies on the effects of alien invasive plants on soil properties in South Africa have concentrated on comparisons between invaded, natural and cleared sites (Witkowski, 1991; Yelenik et al., 2004; Le Maitre et al., 2011), but not on abandoned agricultural fields. Also, most of the above mentioned studies concentrate on changes in soil chemical properties, leaving soil physical properties less studied. The aim of this study was to assess if soils underneath ten-year-old abandoned agricultural fields invaded with $A$. mearnsii have different soil properties compared to soils in adjacent ten-year-old uninvaded abandoned agricultural fields and natural sites in the Eastern Cape province of South Africa. The main research question was whether A. mearnsii invasion of abandoned agricultural fields changes soil properties, namely soil physicochemical properties, penetration resistance, infiltration, hydraulic conductivity, soil repellency and litter mass.

\section{Methods and materials}

\section{Study area}

The study was conducted at Glen View farm $\left(33^{\circ} 26^{\prime} 32.57^{\prime \prime S} ; 26^{\circ} 19^{\prime} 14.12^{\prime \prime E}\right)$ which is located approximately $40 \mathrm{kms}$ outside Grahamstown along the N2 highway in the Eastern Cape Province of South Africa (Fig. 1). The farm currently produce livestock mostly cattle, but abandoned agricultural fields were used for chicory cultivation. Vegetation is classified as Bhisho Thornveld which is characterised by small trees and a short-to-medium, dense sour-grass (Mucina and Rutherford, 2006). Soils are generally loamy and sandy and are of the Adelaide subgroup (Mucina and Rutherford, 2006). Although rainfall in this area falls throughout the year, most of it falls in summer between October and April. Mean annual rainfall approximate $750 \mathrm{~mm}$, whilst mean annual temperature approximate $16^{\circ} \mathrm{C}$ (Mucina and Rutherford, 2006).

\section{Site selection}

Soils were collected within the farm at three different invasion treatments, namely $A$. mearnsii invaded abandoned agricultural fields, uninvaded abandoned agricultural fields and natural sites. The above mentioned three invasion treatments were approximately one km apart. Agricultural activities were abandoned ten years ago in both the $A$. 
mearnsii invaded and the uninvaded abandoned agricultural fields. At each of the above mentioned invasion conditions, three sites were selected for soil sampling. Sites within each invasion treatment were approximately $200 \mathrm{~m}$ apart to provide a measure of independence (Galatowitsch and Richardson, 2005). All A. mearnsii invaded abandoned agricultural fields were dominated by heavy invasions, with canopy cover greater than $70 \%$ and had no underneath vegetation. The uninvaded abandoned agricultural fields were dominated by grasses and herbs. The natural sites were dominated by native trees and shrubs.

At each site a $50 \mathrm{~m}$ transect (from west to east) with the first transect point being underneath the vegetation canopy (in A. mearnsii invaded and natural sites), was established comprising five soil collecting points spaced $10 \mathrm{~m}$ apart. At each point, two soil cores (30 cm apart) were collected monthly in August, September and October of 2015. This resulted in 90 soil cores being collected per month, thus 10 soil cores from 3 invasion treatments and 3 site replicates per treatment. Half of the soil cores collected per sampling point were used for gravimetric soil moisture measurement and the other half for soil repellency measurements. During the month of August, an additional 45 soil cores (one additional soil core per collection point) were collected for soil chemical analysis which was conducted once due to lack of finances. Soils were collected using a soil auger at a depth of $10 \mathrm{~cm}$ after the removal of the overlaying debris. Collection of soils at the above mentioned depth was based on results by Jovanovic et al. (2009) who reported that soil nutrients were represented at a depth of $0-5 \mathrm{~cm}$ underneath Acacia sites. After soil collection, soil nutrient analyses, $\mathrm{pH}$, soil resistivity, gravimetric soil moisture and soil repellency were assessed under laboratory condition at Rhodes University in Grahamstown. Soil penetration resistance, infiltration and litter mass measurements were conducted at each of the soil collecting point for the three above mentioned months.

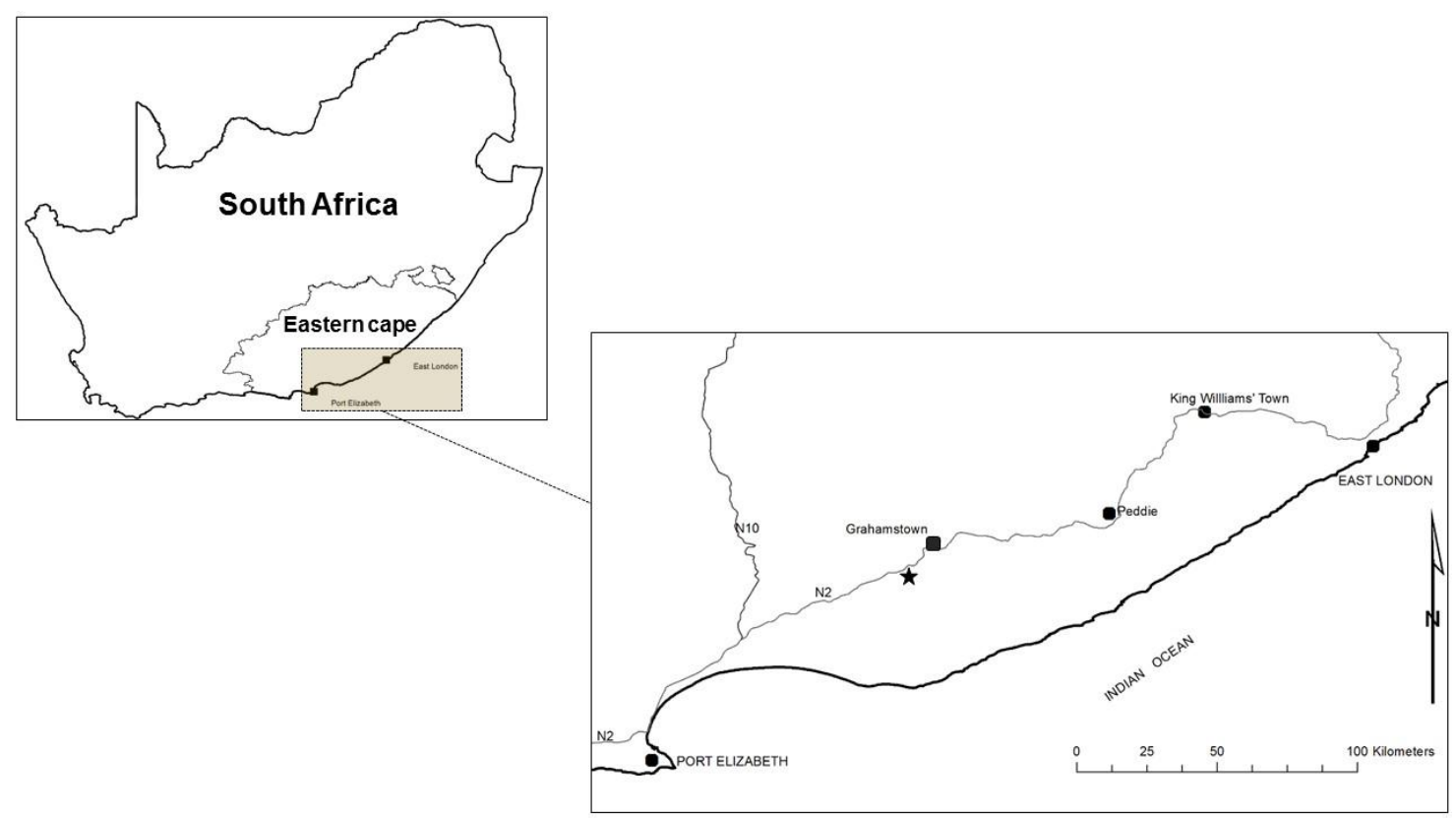

Figure 1. Location of the study area (in asterisk) approximately $40 \mathrm{kms}$ south west of Grahamstown along the N2 highway in the Eastern Cape province of South Africa. 


\section{Soil chemical properties measurements}

Soil P was determined using the Bray-II extraction method (Bray and Krutz, 1945), whilst total carbon was determined using the Walkley-Black method (Chan et al., 2001). Total nitrogen was determined by complete combustion using a Eurovector Euro EA Elemental Analyser, whilst nitrate and ammonium were determined using an auto analyser. All exchangeable cations were extracted in a 1:10 ammonium acetate solution using the centrifuge procedure (Thomas, 1982), filtered and analyzed by atomic absorption spectrometry (SP428, LECO Corporation, USA).

\section{Soil physical properties measurements}

Soil moisture was measured in terms of gravimetric soil moisture expressed as a percentage. Collected soil cores were first sieved to remove stones and plant materials. They were then weighed wet and dried in a drying oven at $105^{\circ} \mathrm{C}$ for 72 hours, then reweighed to obtain the water content (Black, 1965). Soil pH was measured in 1:5 soil$\mathrm{KCl}$ extract (Rhoades, 1982), whilst soil resistivity was measured using a resistivity meter. Soil penetration resistance which measures soil compaction was measured using a mini penetrometer (SOILTEST, Inc.). Litter mass was measured at all soil collection points using a $100 \mathrm{~cm}^{2}$ metal template placed at the litter collection area. The leaf litter within the template was collected down to the humus soil layer. All collected litter samples were first sieved to remove soils, then oven dried at $70^{\circ} \mathrm{C}$ for 72 hours to reduce variability that result from wet litter. The dry litter was then weighed to determine the mass per $100 \mathrm{~cm}^{2}$.

Infiltration rate was measured on all soil collection points using a Mini Disk Infiltrometer (MDI, Decagon Devices, Pullman, WA). The infiltrometer measures the volume of water $(\mathrm{mL})$ that passes from the Infiltrometer into the soils. Infiltration rate was measured from the drop of water in the lower chamber at 30 second intervals for five minutes. Using the method of Zhang (1997), infiltration rate was determined from the measured cumulative infiltration rates over time. Hydraulic conductivity was measured from the infiltration measurements using the van Genuchten-Zhang method (Zhang, 1997).

Soil repellency was measured using the Water Droplet Penetration Time (WDPT) method, which measures how long repellency persists on soils (Bisdom et al., 1993; Doerr et al., 2000). Soils collected from each point were first sieved using a $2 \mathrm{~mm}$ sieve then air-dried over seven days. After drying, 20 grams of sample soils were placed into petri dished and were levelled. The WDPT test was conducted by placing five drops of distilled water on the soil surface and record the time taken for each water droplet to penetrate the soil. The water drops were applied using a hypodermic syringe. The average penetration time of the five drops was taken as representative of the WDPT for each sample. The WDPT categories were (i) wettable when the water drop infiltrated within $5 \mathrm{~s}$, (ii) slightly repellent when the water drop infiltrated between 5 and $60 \mathrm{~s}$, (iii) strongly repellent when the water drop infiltrated between 60 and $600 \mathrm{~s}$, (iv) severely repellent when the water drop infiltrated between 600 and $3600 \mathrm{~s}$ and (v) extremely repellent when the water drop infiltrated above $3600 \mathrm{~s}$ (Bisdom et al., 1993).

\section{Statistical analysis}

Data were analyzed using STATISTICA version 12 (Statsoft Inc, 2012). Proof of normality and proof of homogeneity of variances were tested using Kolmogorov- 
Smirnov tests and Levene's test respectively and data were normally distributed. Soil chemical properties, $\mathrm{pH}$ and resistivity comparisons between A. mearnsii invaded abandoned agricultural fields, uninvaded abandoned agricultural fields and natural sites were analyzed using one-way ANOVA since data was collected only once in August. Gravimetric soil moisture content, soil penetration resistance, litter mass and soil hydraulic conductivity, which were all collected monthly on the same transect were analyzed using repeated measures ANOVA. Soil repellency categories were analyzed using the Chi-squared test. Where ANOVAs were significant, the Tukey's HSD unequal $n$ test was used to determine differences between invasion treatments at $\mathrm{P}<0.05$.

\section{Results}

\section{Soil chemical properties}

Significant $(\mathrm{p}<0.01)$ differences between the three different invasion treatments were found in soil $\mathrm{P}$, total $\mathrm{C}$ and exchangeable cations of $\mathrm{Na}$ and $\mathrm{Mg}$ (Table 1). Of the above mentioned significant differences only soil $\mathrm{P}$ was significantly higher in uninvaded abandoned agricultural fields compared to A. mearnsii invaded abandoned agricultural fields and natural sites (Table 1). Site comparisons of the observed significant differences in soil $\mathrm{P}$ showed that the differences were more visible in all three sites. Total $\mathrm{C}$ and exchangeable cations of $\mathrm{Na}$ and $\mathrm{Mg}$ were significantly higher in A. mearnsii invaded abandoned agricultural fields than in natural sites and uninvaded abandoned agricultural fields (Table 1). Significant differences in total $\mathrm{C}, \mathrm{Na}$ and $\mathrm{Mg}$ were visible in sites two and three than in site one. Soil total $\mathrm{N}, \mathrm{NO}_{3}-\mathrm{N}, \mathrm{NH}_{4}-\mathrm{N}$ and the exchangeable cations of $\mathrm{K}$ and Ca showed no significant $(\mathrm{p}>0.05)$ differences between the three different invasion treatments (Table 1).

\section{Soil physical properties}

\section{Soil moisture, $\mathrm{pH}$ and resistivity}

Gravimetric soil moisture content was significantly $(\mathrm{p}<0.001)$ higher in uninvaded abandoned agricultural fields compared to A. mearnsii invaded abandoned agricultural fields and natural sites (Table 2). Similarly, monthly comparisons on gravimetric soil moisture content as well as interactions between invasion and months showed significant $(\mathrm{p}<0.01)$ differences (Table 2). The months of August and September had high (mean: $11.87 \%$ and $11.81 \%$ respectively) gravimetric soil moisture content in uninvaded abandoned agricultural fields compared to the month of October (mean: 9.47\%). Contrary, the months of September and October (mean: $4.71 \%$ and $4.20 \%$ respectively) had high gravimetric soil moisture content in A. mearnsii invaded abandoned agricultural fields compared to the month of August (mean: 2.45\%). Similarly, the months of September and October (mean: 3.73\% and 3.87\% respectively) had high gravimetric soil moisture content compared in natural sites compared to the month of August (mean: 1.88\%). Site comparisons for gravimetric soil moisture content showed significant $(\mathrm{p}<0.001)$ differences in all three sites for all the three months.

Soil $\mathrm{pH}$ was significantly $(\mathrm{p}<0.001)$ higher in uninvaded abandoned agricultural fields compared to A. mearnsii invaded abandoned agricultural fields and natural sites (Table 1). Site comparisons for soil $\mathrm{pH}$ showed that significant differences were more 
visible in all the three sites. Soil resistivity, showed no significant $(\mathrm{p}>0.05)$ differences between the three different invasion treatments (Table 1).

Table 1. Soil physico-chemical properties of soil samples taken from invaded abandoned agricultural fields, uninvaded abandoned agricultural fields and natural sites. Data are means \pm SE and one-way ANOVA results are shown $\left({ }^{*} p<0.05, * * p<0.01, * * * p<0.001\right)$. $N S=$ not significant at $p>0.05$. Values within columns with different letter superscripts are significantly different.

\begin{tabular}{|c|c|c|c|c|}
\hline $\begin{array}{l}\text { Soil } \\
\text { Properties }\end{array}$ & $\begin{array}{l}\text { Invaded abandoned } \\
\text { agricultural fields }\end{array}$ & $\begin{array}{l}\text { Uninvaded abandoned } \\
\text { agricultural fields }\end{array}$ & $\begin{array}{c}\text { Natural } \\
\text { sites }\end{array}$ & $\begin{array}{l}\text { One-way } \\
\text { ANOVA }\end{array}$ \\
\hline $\mathrm{pH}$ & $\begin{array}{l}4.05 \pm \\
0.06^{\mathrm{c}}\end{array}$ & $\begin{array}{l}5.29 \pm \\
0.08^{\mathrm{a}} \\
\end{array}$ & $\begin{array}{l}4.64 \pm \\
0.017^{\mathrm{b}}\end{array}$ & $28.18 * * *$ \\
\hline $\begin{array}{l}\text { Soil } \\
\text { Resistivity } \\
\text { (Ohm) }\end{array}$ & $\begin{array}{l}4136.73 \pm \\
942.20^{\mathrm{a}}\end{array}$ & $\begin{array}{l}5025.33 \pm \\
159.03^{\mathrm{a}}\end{array}$ & $\begin{array}{l}5001.40 \pm \\
840.04^{\mathrm{a}}\end{array}$ & $0.48 \mathrm{~ns}$ \\
\hline \multicolumn{5}{|c|}{ Total nutrient concentrations $(\mathrm{mg} / \mathrm{kg})$} \\
\hline P Bray II & $\begin{array}{l}7.73 \pm \\
1.98^{\mathrm{c}} \\
\end{array}$ & $\begin{array}{l}26.87 \pm \\
1.90^{\mathrm{a}} \\
\end{array}$ & $\begin{array}{l}18.13 \pm \\
3.00^{\mathrm{b}}\end{array}$ & $16.63 * * *$ \\
\hline Total C & $\begin{array}{l}10226.67 \pm \\
1270.86^{\mathrm{a}}\end{array}$ & $\begin{array}{l}4813.33 \pm \\
479.07^{\mathrm{b}}\end{array}$ & $\begin{array}{l}7080.00 \pm \\
961.11^{\mathrm{ab}}\end{array}$ & $8.01 * *$ \\
\hline Total $\mathrm{N}$ & $\begin{array}{l}262.00 \pm \\
53.16^{\mathrm{a}}\end{array}$ & $\begin{array}{l}311.33 \pm \\
58.34^{\mathrm{a}} \\
\end{array}$ & $\begin{array}{l}295.33 \pm \\
62.52^{\mathrm{a}}\end{array}$ & $0.19 \mathrm{~ns}$ \\
\hline $\mathrm{NO}_{3}-\mathrm{N}$ & $\begin{array}{l}1.09 \pm \\
0.19^{\mathrm{a}} \\
\end{array}$ & $\begin{array}{l}2.05 \pm \\
0.59^{\mathrm{a}}\end{array}$ & $\begin{array}{l}1.29 \pm \\
0.17^{\mathrm{a}}\end{array}$ & $1.87 \mathrm{~ns}$ \\
\hline $\mathrm{NH}_{4}-\mathrm{N}$ & $\begin{array}{l}8.98 \pm \\
1.24^{\mathrm{a}} \\
\end{array}$ & $\begin{array}{l}8.35 \pm \\
0.56^{\mathrm{a}} \\
\end{array}$ & $\begin{array}{l}8.81 \pm \\
1.11^{\mathrm{a}} \\
\end{array}$ & $0.10 \mathrm{~ns}$ \\
\hline \multicolumn{5}{|c|}{ Exchangeable cations (mg/kg) } \\
\hline K & $\begin{array}{l}52.00 \pm \\
6.18^{\mathrm{a}} \\
\end{array}$ & $\begin{array}{l}39.00 \pm \\
1.40^{\mathrm{a}} \\
\end{array}$ & $\begin{array}{l}49.01 \pm \\
5.05^{\mathrm{a}} \\
\end{array}$ & $2.17 \mathrm{~ns}$ \\
\hline $\mathrm{Na}$ & $\begin{array}{l}29.90 \pm \\
3.52^{\mathrm{a}}\end{array}$ & $\begin{array}{l}12.88 \pm \\
0.38^{\mathrm{b}}\end{array}$ & $\begin{array}{l}21.93 \pm \\
3.46^{\mathrm{ab}}\end{array}$ & $8.87^{* * *}$ \\
\hline $\mathrm{Ca}$ & $\begin{array}{l}156.27 \pm \\
17.74^{\mathrm{a}}\end{array}$ & $\begin{array}{l}214.00 \pm \\
15.27^{\mathrm{a}}\end{array}$ & $\begin{array}{l}179.60 \pm \\
16.42^{\mathrm{a}}\end{array}$ & $3.09 \mathrm{~ns}$ \\
\hline $\mathrm{Mg}$ & $\begin{array}{l}55.92 \pm \\
5.62^{\mathrm{a}} \\
\end{array}$ & $\begin{array}{l}38.00 \pm \\
1.03^{\mathrm{b}}\end{array}$ & $\begin{array}{l}45.12 \pm \\
3.28^{\mathrm{ab}}\end{array}$ & $5.63 * *$ \\
\hline
\end{tabular}

\section{Soil penetration and litter mass}

Soil penetration resistance levels were significantly $(\mathrm{p}<0.001)$ higher in A. mearnsii invaded abandoned agricultural fields compared to uninvaded abandoned agricultural fields and natural sites (Table 2). Site comparisons for soil penetration resistance levels showed significant $(\mathrm{p}<0.001)$ differences in all three sites for all the three months. However, monthly comparisons and interactions between months and invasion on soil penetration resistance levels showed no significant $(\mathrm{p}>0.05)$ differences (Table 2).

Litter mass was significantly $(\mathrm{p}<0.001)$ higher in $A$. mearnsii invaded abandoned agricultural fields compared to uninvaded abandoned agricultural fields and natural sites (Table 2). Site comparisons for litter mass showed significant ( $\mathrm{p}<0.001)$ differences in all three sites for all the three months. Monthly comparisons on litter mass showed no significant $(\mathrm{p}>0.05)$ differences between the three different invasion treatments, whereas, interactions between invasion and months showed significant $(\mathrm{p}<0.01)$ differences (Table 2). 
Table 2. Comparison of gravimetric soil moisture content, soil penetration resistance levels and litter mass between soils underneath invaded abandoned agricultural fields, uninvaded abandoned agricultural fields and natural site. Data are means \pm se and repeated ANOVA results are shown $\left({ }^{*} p<0.05,{ }^{*} p<0.01,{ }^{* * *} p<0.001\right)$. NS = not significant at $p>0.05$. Values within columns with different letter superscripts are significantly different.

\begin{tabular}{|c|c|c|c|c|c|c|c|c|c|c|c|c|}
\hline & \multicolumn{3}{|c|}{ August 2015} & \multicolumn{3}{|c|}{ September 2015} & \multicolumn{3}{|c|}{ October 2015} & \multicolumn{3}{|c|}{ Repeated ANOVA (F-values) } \\
\hline & $\begin{array}{l}\text { Invaded } \\
\text { abandoned } \\
\text { agricultural } \\
\text { fields }\end{array}$ & $\begin{array}{l}\text { Uninvaded } \\
\text { abandoned } \\
\text { agricultural } \\
\text { fields }\end{array}$ & $\begin{array}{l}\text { Natural } \\
\text { sites }\end{array}$ & $\begin{array}{l}\text { Invaded } \\
\text { abandoned } \\
\text { agricultural } \\
\text { fields }\end{array}$ & $\begin{array}{l}\text { Uninvaded } \\
\text { abandoned } \\
\text { agricultural } \\
\text { fields }\end{array}$ & $\begin{array}{l}\text { Natural } \\
\text { sites }\end{array}$ & $\begin{array}{l}\text { Invaded } \\
\text { abandoned } \\
\text { agricultural } \\
\text { fields }\end{array}$ & $\begin{array}{l}\text { Uninvaded } \\
\text { abandoned } \\
\text { agricultural } \\
\text { fields }\end{array}$ & $\begin{array}{l}\text { Natural } \\
\text { sites }\end{array}$ & Invasion & Months & $\begin{array}{l}\text { Invasion } \\
\mathrm{X} \\
\text { months }\end{array}$ \\
\hline $\begin{array}{l}\text { Gravimetric } \\
\text { soil } \\
\text { moisture } \\
\text { content }(\%)\end{array}$ & $\begin{array}{l}2.45 \pm \\
0.38^{\mathrm{b}}\end{array}$ & $\begin{array}{l}11.87 \pm \\
0.40^{\mathrm{a}}\end{array}$ & $\begin{array}{l}1.89 \pm \\
0.34^{\mathrm{b}}\end{array}$ & $\begin{array}{l}4.71 \pm \\
0.62^{\mathrm{b}}\end{array}$ & $\begin{array}{l}11.81 \pm \\
0.61^{\mathrm{a}}\end{array}$ & $\begin{array}{l}3.73 \pm \\
0.38^{\mathrm{b}}\end{array}$ & $\begin{array}{l}4.20 \pm \\
0.37^{\mathrm{b}}\end{array}$ & $\begin{array}{l}9.47 \pm \\
0.37^{\mathrm{a}}\end{array}$ & $\begin{array}{l}3.87 \pm \\
0.37^{\mathrm{b}}\end{array}$ & $303.11 * * *$ & $7.45 * *$ & $8.10 * * *$ \\
\hline $\begin{array}{l}\text { Soil } \\
\text { penetration } \\
\text { resistance } \\
\text { levels }\end{array}$ & $\begin{array}{l}2.33 \pm \\
0.11^{\mathrm{a}}\end{array}$ & $\begin{array}{l}0.11 \pm \\
0.02^{\mathrm{c}}\end{array}$ & $\begin{array}{l}0.85 \pm \\
0.12^{\mathrm{b}}\end{array}$ & $\begin{array}{l}2.40 \pm \\
0.13^{\mathrm{a}}\end{array}$ & $\begin{array}{l}0.14 \pm \\
0.01^{\mathrm{c}}\end{array}$ & $\begin{array}{l}0.90 \pm \\
0.13^{\mathrm{b}}\end{array}$ & $\begin{array}{l}2.42 \pm \\
0.09^{\mathrm{a}}\end{array}$ & $\begin{array}{l}0.12 \pm \\
0.01^{\mathrm{c}}\end{array}$ & $\begin{array}{l}1.01 \pm \\
0.13^{\mathrm{b}}\end{array}$ & $403.51 * * *$ & $0.60 \mathrm{~ns}$ & $0.16 \mathrm{~ns}$ \\
\hline $\begin{array}{l}\text { Litter mass } \\
\left(\mathrm{g} / 100 \mathrm{~m}^{2}\right)\end{array}$ & $\begin{array}{l}132.85 \pm \\
14.64^{\mathrm{a}}\end{array}$ & $\begin{array}{l}27.49 \pm \\
2.46^{\mathrm{b}}\end{array}$ & $\begin{array}{l}42.69 \pm \\
4.44^{\mathrm{b}}\end{array}$ & $\begin{array}{l}154.30 \pm \\
12.42^{\mathrm{a}}\end{array}$ & $\begin{array}{l}20.03 \pm \\
1.36^{\mathrm{c}}\end{array}$ & $\begin{array}{l}63.01 \pm \\
6.16^{\mathrm{b}}\end{array}$ & $\begin{array}{l}121.77 \pm \\
4.49^{\mathrm{a}}\end{array}$ & $\begin{array}{l}26.98 \pm \\
1.58^{\mathrm{c}}\end{array}$ & $\begin{array}{l}67.31 \pm \\
4.98^{\mathrm{b}}\end{array}$ & $183.92 * * *$ & $1.87 \mathrm{~ns}$ & $3.39 *$ \\
\hline
\end{tabular}




\section{Soil infiltration and conductivity}

Infiltration rates were significantly $(\mathrm{p}<0.001)$ higher in uninvaded abandoned agricultural fields compared to A. mearnsii invaded abandoned agricultural fields and natural sites for all the three months. Average infiltration rate after five minutes was $15.47 \mathrm{~cm}$ in August, $14.67 \mathrm{~cm}$ in September and $12.67 \mathrm{~cm}$ in October in uninvaded abandoned agricultural fields compared to $4.47 \mathrm{~cm}$ in August, $3.47 \mathrm{~cm}$ in September and $1.60 \mathrm{~cm}$ in October in A. mearnsii invaded abandoned agricultural fields agricultural fields and $5.60 \mathrm{~cm}$ in August, $5.73 \mathrm{~cm}$ in September and $4.00 \mathrm{~cm}$ in October in natural sites (Fig. 2A, B, and $C$ ). Site comparisons for infiltration rates showed significant $(\mathrm{p}<0.001)$ differences in all sites for all the three months.

Soil hydraulic conductivity was significantly $(\mathrm{p}<0.001)$ higher in uninvaded abandoned agricultural fields compared to A. mearnsii invaded abandoned agricultural fields and natural sites (Fig. 2D). However, monthly comparisons for soil hydraulic conductivity as well as interactions between months and invasion showed no significant $(\mathrm{p}>0.05)$ differences (Fig. 2D).
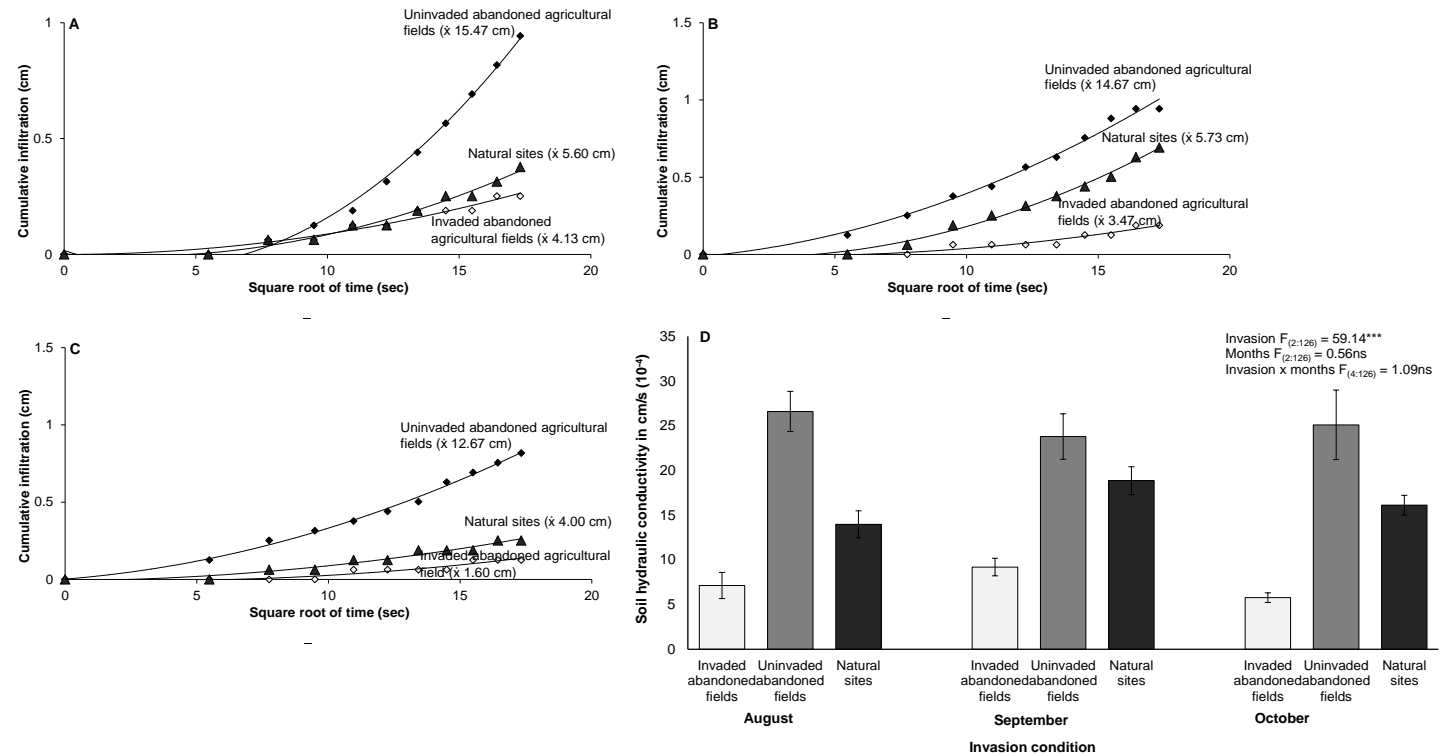

Figure 2. Comparison of cumulative infiltration in the months (A) August, (B) September, $(C)$ October and $(D)$ soil hydraulic conductivity for all three months between soils underneath invaded abandoned agricultural fields, uninvaded abandoned agricultural fields and natural sites. Points and bars are means and repeated ANOVA results are shown $\left({ }^{*} p<0.05,{ }^{* *} p<\right.$ $0.01, * * * p<0.001) . N S=$ not significant at $p>0.05$.

\section{Soil repellency}

All soils collected from uninvaded abandoned agricultural fields were wettable for all the three months (Fig. 3). Soils from A. mearnsii invaded abandoned agricultural fields were slightly, strongly or severely repellent for all the three months (Fig. 3). Five (33\%) of the 15 soil samples collected from A. mearnsii invaded abandoned agricultural fields in August and October as well as six (40\%) of the soil samples collected from the same above mentioned fields in September were slightly repellent (Fig. 3). Seven (47\%) of the soils collected from A. mearnsii invaded abandoned agricultural fields in September 
and October as well as eight (53\%) of the soils collected from the same above mentioned fields in August were strongly repellent (Fig. 3). Some 20\% in October and $13 \%$ in August and September of the soils collected from A. mearnsii invaded abandoned agricultural fields were severely repellent (Fig. 3). Ten (67\%) of the soils collected in natural sites in August and October as well as seven (47\%) of the soils collected from the same above mentioned sites in September were wettable. The remaining five (33\%) soil samples collected in natural sites in August and October as well as eight $(55 \%)$ of the soils collected from the same above mentioned sites in September were slightly repellent (Fig. 3). Chi-squared test showed significant ( $\mathrm{p}<$ $0.001)$ differences in WDPT categories between the three different invasion treatments for all the three months (Fig. 3).

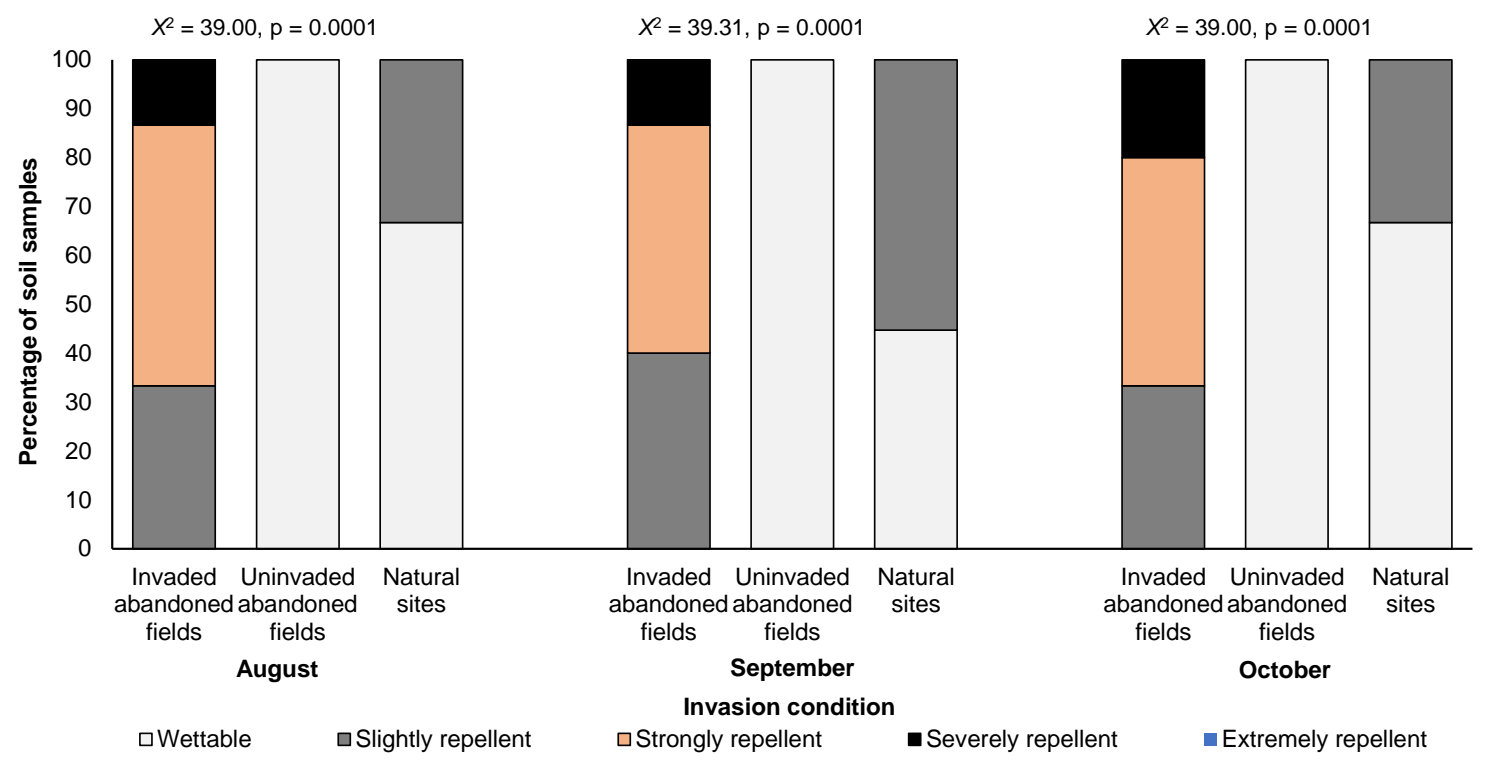

Figure 3. Distribution of soil repellency classes using the Water Droplet Penetration Time (WDPT) method in soil samples taken from underneath invaded abandoned agricultural fields, uninvaded abandoned agricultural fields and natural sites.

\section{Discussion}

Results on soil chemical properties were varied, with some nutrients e.g. total C being higher in $A$. mearnsii invaded abandoned agricultural fields, whilst soil $\mathrm{P}$ was higher in uninvaded abandoned agricultural fields. The study expected soil chemical properties in uninvaded abandoned agricultural fields to be high due to past fertilization (Jiao et al., 2013); however, this was only true for soil P. The fact that measured soil chemical properties in natural sites and uninvaded abandoned agricultural fields were lower than in A. mearnsii invaded abandoned agricultural fields points to the presence of $A$. mearnsii as the possible cause of the changes in soil chemical properties.

Indeed, several studies have reported that invasion by alien Acacias cause changes in soil nutrients (Yelenik et al., 2004; Marchante et al., 2008). Musil (1993) and Yelenik et al. (2004) reported high soil nutrients e.g. soil N, Ca, Mg, K, Mn and B concentrations in A. saligna invaded sites compared to natural fynbos sites. Marchante et al. (2008) showed that $A$. longifolia invaded sites have high soil $\mathrm{C}$ and $\mathrm{N}$ pools than uninvaded sites in Portuguese coastal dunes. Contrary, Rodríguez-Echeverría et al. (2013) reported 
converse effects of Acacia species, showing higher organic matter, soil $\mathrm{K}$ and $\mathrm{N}$ in soils collected underneath native Pinus pinaster species than in soil collected from $A$. dealbata invaded sites. The above mentioned examples seem to show mixed results regards the effect of Acacia invasions on soil nutrients.

Several factors can explain the observed changes in soil nutrients underneath $A$. mearnsii invaded abandoned agricultural fields e.g. litter accumulation and litter decomposition. The accumulation of litter underneath Acacia trees has been shown to be one of the drivers of soil nutrients increase, especially N and C (Yelenik et al., 2004). In this study litter mass were three times higher in A. mearnsii invaded abandoned agricultural fields compared to uninvaded abandoned agricultural fields and natural sites. Acacia litter has been shown to have high $\mathrm{N}$ concentrations which in turn results in increased soil $\mathrm{N}, \mathrm{NO}_{3}-\mathrm{N}$ and $\mathrm{NH}_{4}-\mathrm{N}$ (Yelenik et al., 2004). However, in this study the reported high litter content in invaded abandoned agricultural fields did not result in high soil $\mathrm{N}, \mathrm{NO}_{3}-\mathrm{N}$ and $\mathrm{NH}_{4}-\mathrm{N}$. This could be a result of slow litter decomposition rates as suggested by Witkowski (1991) who reported low litter decomposition rates in $A$. saligna sites compared to Leucospermum parile sites, which is a fynbos indigenous shrub. The suspicion of slow litter decomposition at A. mearnsii invaded abandoned agricultural fields is supported by the fact that soils underneath $A$. mearnsii were compact and with little moisture, this known to affect bacterial and fungal activities (Pupin et al., 2009).

A. mearnsii invasion of abandoned agricultural fields seem to have triggered several changes in the physical nature of the soils compared to uninvaded abandoned agricultural fields and natural sites. The above mentioned changes in the physical nature of the soils were probably related to litter and the organic matter content in the soils which affects soil development, aggregation, macro-pores, bacterial and fungal activities (Jeddi et al., 2009). Although the litter of A. mearnsii has been reported to have less sources of hydrophobic substances (Scott, 2000), it still can contain molds, fungi and other agents of decomposition that cause the litter layer to be hydrophobic. Ens et al. (2010) reported that A. longifolia leaves possess hydrophobic compounds which causes soil hydrophobicity, which in turn triggers soil compaction, reduced water infiltration and hydraulic conductivity. Also, plant canopy has been reported to influence the intensity and duration of both light and water received by the soils (Kahi et al., 2009), which in turn affect soil moisture and soil temperature. Soils in uninvaded abandoned agricultural fields were not compact and had high infiltration rates. This observation can be explained by previous tilling. Indeed, previous soil tilling has been reported to reduce soil compaction (Hamza and Anderson, 2005) and improve infiltration (Olson et al., 2013).

Soils underneath $A$. mearnsii invaded abandoned agricultural fields were more repellent compared to soils in uninvaded abandoned agricultural fields and natural sites. This could be a result of the reported changes in soil physical properties as well as litter availability. Neinhuis and Barthlott (1997) reported that Mimosaceae species e.g. A. dealbata and A. glaucoptera have water repellent leaves. These leaves contain hydrophobic organic substances that when in the soils can cause water repellency (Neinhuis and Barthlott, 1997). These hydrophobic organic substances have been reported to cover soil particles and reduce the attraction between soil and water therefore causing repellency (Doerr et al., 2000) which also led to decrease infiltration which was observed in this study. Scott (2000) reported that soils underneath both Eucalyptus and Acacia plantations were repellent compared to soils underneath 
indigenous forest of South Africa and attributed it to canopy cover and plant litter. Soils in uninvaded abandoned agricultural fields were wettable this likely because of tilling that was done in the past. Blanco-Canqui (2011) reported that no-tillage triggers soil repellency, whereas, Eynard et al. (2004) found no significant differences in soil repellency between no-tillage and tillage.

The study concludes that the invasion of abandoned agricultural fields by $A$. mearnsii ten years ago has triggered changes in both soil physical properties and some chemical nutrients (total C). The presence of these invasive trees and their ability to produce huge amounts of litter which is suspected to contain hydrophobic substances seem to be the main driver of the reported changes in soil properties.

Acknowledgements. Thanks to Rhodes University for the funding under the Rhodes University Research Committee (RC) Grant. I also thank the Department of Environmental Science for the equipment and transport. Lastly, thanks to Clen View farm owners for the permission to work in the farm.

\section{REFERENCES}

[1] Bisdom, E. B. A., Dekker, L. W., Schoute, J. F. T. (1993): Water repellency of sieve fractions from sandy soils and relationships with organic material and soil structure. Geoderma, 56: 105-118.

[2] Black, C. A. (1965): Methods of soil analysis: Part I physical and mineralogical properties. - American society of agronomy, Madison, Wasconsin, USA.

[3] Blanco-Canqui, H. (2011): Does no-till farming induce water repellency to soils? - Soil Use \& Management 27: 2-9.

[4] Bray, R. H., Krutz, L. T. (1945): Determination of total, organic and available forms of phosphorus in soils. - Soil Science 59: 39-45.

[5] Chambers, J. C., Eldredge, E. P., Snyder, K. A., Board, D. I., Forbis De Queiroz, T., Hubbard, V. (2014): Restoring abandoned agricultural lands in cold desert shrublands: Tradeoffs between water availability and invasive species. - Invasive Plant Science \& Management 7(1): 176-189.

[6] Chan, K. Y., Bowman, A., Oates, A. (2001): Oxidizible organic carbon fractions and soil quality changes in an Oxic Paleustalf under different pasture leys. - Soil Science Society of America Journal 166: 61-67.

[7] Doerr, S. H., Shakesby, R. A., Walsh, R. P. D. (2000): Soil water repellency: its causes, characteristics and hydro-geomorphological significance. - Earth-Science Reviews 51: 33-65.

[8] Dye, P., Jarmain, C. (2004): Water use by black wattle (Acacia mearnsii): implications for the link between removal of invading trees and catchment streamflow response. South African Journal of Science 100: 40-44.

[9] Ens, E., French, K. O., Bremner, J. B., Korth, J. (2010): Novel technique shows different hydrophobic chemical signatures of exotic and indigenous plant soils with similar effects of extracts on indigenous species seedling growth. - Plant Soil 326: 403-414.

[10] Esler, K. J., Holmes, P. M., Richardson, D. M., Witkowski, E. T. F. (2008): Riparian vegetation management in landscapes invaded by alien plants: insights from South Africa. - South African Journal of Botany 74: 401-552.

[11] Eynard, A., Schumacher, T. E., Lindstrom, M. J., Malo, D. D., Kohl, R. A. (2004): Wettability of soil aggregates from cultivated and uncultivated Ustolls and Usterts. Australian Journal of Soil Research 42: 163-170. 
[12] Galatowitsch, S., Richardson, D. M. (2005): Riparian scrub recovery after clearing of invasive alien trees in headwater streams of the Western Cape, South Africa. - Biological Conservation 122: 509-521.

[13] Hamza, M. A., Anderson, W. K. (2005): Soil compaction in cropping systems: A review of the nature, causes and possible solutions. - Soil \& Tillage Research 82: 121-145.

[14] Hobbs, R. J., Cramer, V. A. (2007): Why old fields? Socioeconomic and ecological causes and consequences of land abandonment. - In: Cramer, V. A., Hobbs, R. J. (eds) Old fields: Dynamics and restoration of abandoned farmland, Island Press, Washington D.C., pp, 1-14.

[15] Jeddi, K., Cortina, J., Chaieb, M. (2009): Acacia salicina, Pinus halepensis and Eucalyptus occidentalis improve soil surface conditions in arid southern Tunisia. Journal of Arid Environments 73: 1005-1013.

[16] Jiao, F., Wen, Z-M., An, S-S., Yuan, Z. (2013): Successional changes in soil stoichiometry after land abandonment in Loess Plateau, China. - Ecological Engineering 58: 249-254.

[17] Jovanovic, N. Z., Israel, S., Tredoux, G., Soltau, L., Le Maitre, D., Rusinga, F., Rozanov, A., Van Der Merwe, N. (2009): Nitrogen dynamics in land cleared of alien vegetation (Acacia saligna) and impacts on groundwater at Riverlands Nature Reserve (Western Cape, South Africa). - Water Sa 35: 37-44.

[18] Kahi, C. H., Ngugi, R. K., Mureithi, S. M., Ng'ethe, J. C. (2009): The canopy effects of Prosopis juliflora (DC.) and Acacia tortilis (Hayne) trees on herbaceous plants species and soil physico-chemical properties in Njemps flats, Kenya. - Tropical \& Sub-tropical Agroecosystems 10: 441-449.

[19] Le Maître, D. C., Gaertner, M., Marchante, E., Ens, E. J., Holmes, P. M., Pauchard. A., O'Farrell, P. J., Rogers, A. M., Blanchard, R., Blignaut, J., Richardson, D. M. (2011): Impacts of invasive Australian acacias: implications for management and restoration. Diversity \& Distribution 17: 1015-1029.

[20] MacDonald, D., Crabtree, J. R., Wiesinger, G., Dax, T., Stamou, N., Fleury, P., Gutierrez-Lazpita, J., Gibon, A. (2000): Agricultural abandonment in mountain areas of Europe: Environmental consequences and policy response. - Journal of Environmental Management 59: 47-69.

[21] Marchante, E., Kjøller, A., Struwe, S., Freitas, H. (2008): Short- and long-term impacts of Acacia longifolia invasion on the belowground processes of a Mediterranean coastal dune ecosystem. - Applied Soil Ecology 40: 210-217.

[22] Milton, S.J. (2004): Grasses as invasive alien plants in South Africa. - South African Journal of Science 100: 69-75.

[23] Mucina, L., Rutherford, M. C. (2006): The vegetation of South Africa, Lesotho and Swaziland. - Strelitzia 19, South African National Biodiversity institute, Pretoria.

[24] Musil, C.F. (1993): Effects of invasive Australian acacias on the regeneration, growth and nutrient chemistry of South African lowland Fynbos. - Journal of Applied Ecology 30: 361-372.

[25] Neinhuis, C., Barthlott, W. (1997): Characterization and distribution of water-repellent, self-cleaning plant surfaces. - Annals of Botany 79: 667-677.

[26] Olson, N. C., Gulliver, J. S., Nieber, J. L., Kayhanian, M. (2013): Remediation to improve infiltration into compact soils. - Journal of Environmental Management 117: 8595.

[27] Pupin, B., Da Silva Freddi, O., Nahas, E. (2009): Microbial alterations of the soil influenced by induced compaction. - Revista Brasileira de Ciência do Solo 33: 12071213.

[28] Rey Benayas, J. M., Martins, A., Nicolau, J. M., Schulz, J. J. (2007): Abandonment of agricultural land: an overview of drivers and consequences. - CAB Reviews: Perspectives in Agriculture, Veterinary Science, Nutrition \& Natural Resources 2(57): 1-14. 
[29] Rhoades, J. D. (1982): Cation exchanger capacity. - In: Page, A. L., Miller, A. L., Keeney, R. H. (eds) Methods of soil Analysis, $2^{\text {nd }}$ Edition, American Society of Agronomy, Madison, WI, pp. 149-157.

[30] Rodríguez-Echeverría, S., Afonso, C., Correia, M., Lorenzo, P., Roiloa, S. R. (2013): The effect of soil legacy on competition and invasion by Acacia dealbata Link. - Plant Ecology 214: 1139-1146.

[31] Ruwanza, S., Musil, C. F., Esler, K. J. (2012): Sucrose application is ineffectual as a restoration aid in a transformed southern African lowland fynbos ecosystem. - South African Journal of Botany 80: 1-8.

[32] Scott, D. F. (2000): Soil wettability in forested catchments in South Africa; as measured by different methods and as affected by vegetation cover and soil characteristics. Journal of Hydrology 231-232: 87-104.

[33] Statsoft, Inc. (2012): STATISTICA (Data Analysis Software System), Version 12. http://www. statsoft.com.

[34] Thomas, G. W. (1982): Exchangeable cations. - In: Page, A. L., Miller, A. L., Keeney, R. H. (eds) Methods of soil Analysis, $2^{\text {nd }}$ Edition, American Society of Agronomy, Madison, WI, pp. 159-164.

[35] Witkowski, E. T. F. (1991): Effects of invasive alien acacias on nutrient cycling in the coastal lowlands of the Cape Fynbos. - Journal of Applied Ecology 28: 1-15.

[36] Yelenik, S. G., Stock, W. D., Richardson, D. M. (2004): Ecosystem impacts of invasive Acacia saligna in South African Fynbos. - Restoration Ecology 12: 44-51.

[37] Zhang, R. (1997): Determination of soil sorptivity and hydraulic conductivity from the disk infiltrometer. - Soil Science Society of America Journal 61: 1024-1030. 